\title{
ก่ำ่ำ talentabijois
}

\section{COMPARISON OF POLYMORPHISM rs2070672 CYP2E1 GENE PROPORTION IN EARLY AND ADVANCED STAGE OF UNDIFFERENTIATED TYPE NASOPHARYNGEAL CARCINOMA IN BALINESE}

\author{
I Ketut Suanda ${ }^{1}$ I Gde Ardika Nuaba ${ }^{1}$, Ni Putu Ayu Wiarni Susanthi ${ }^{{ }^{*}}$ \\ ${ }^{I}$ Department of Otorhinolaryngology, Medical Faculty of Udayana University, Sanglah Hospital, Denpasar, Indonesia
}

\begin{abstract}
Introduction: Nasopharyngeal carcinoma is the most common malignancy in the ENT field. The cause of nasopharyngeal carcinoma is multifactorial. One of the risk factors for an increase in nasopharyngeal carcinoma is the rs2070672 polymorphism of the CYP2E1 gene.

Objective: To determine the rs2070672 CYP2E1 gene polymorphism proportion in early and advanced stage undifferentiated type NPC subjects in Balinese.

Method: This research is a cross-sectional comparative study. The case population was all subjects with undifferentiated type NPC in the ENT outpatient clinic at Sanglah General Hospital Denpasar. This study use 65 samples. Data collected in the form of subject characteristics and rs2070672 CYP2E1 gene polymorphisms which examined by the ARMS-PCR technique.

Result: The average age of the sample was 48.1 years, the most were male as many as 48 subjects $(73.8 \%)$, and the highest was the advanced stage as many as 56 subjects $(86.2 \%)$. In the chi-square test, the proportion of polymorphisms in the advanced stage was 2.357 times higher than the early stages. The results of the multivariate analysis using logistic regression proved that the rs2070672 CYP2E1 gene polymorphism at the advanced stage was 7.469 times higher than the early stage.

Conclusion: There is a difference in the proportion of rs2070672 CYP2E1 gene polymorphism in undifferentiated type NPC of Balinese, where the advanced stage is higher than the early stage.
\end{abstract}

\section{Article Info}

Keywords:

NPC, Balinese, polymorphism, rs2070672 CYP2E1 gene

\section{*Corresponding author}

Address: Jl. P.B. Sudirman, Dangin Puri Klod, Kec. Denpasar Bar., Kota Denpasar, Bali 80232

e-mail: ayu.wiarnisusanthi@gmail.com

\section{INTRODUCTION}

Nasopharyngeal carcinoma (NPC) is a malignancy of the surface epithelium in the nasopharynx. The incidence rate in men has doubled compared to women. The incidence of NPC is 1.2 per 100,000 populations per year, with diverse geographical spreads throughout the world [1]. The prevalence of NPC in Indonesia is highest in the 4-5 decade with a ratio between men and women is 2-3:1 and reaches 4.7 per 100,000 populations per year [2].

Nasopharyngeal carcinoma risk factors consist of internal and external factors. Internal factors are genetic mechanisms. External factors are Epstein-Barr virus (EBV) infection, exposure to cigarette smoke, wood dust, formaldehyde, and consuming preserved food [3].

One of the genes polymorphisms at risk for NPC is the cytochrome P450 family 2 subfamily E polypeptide 1 (CYP2E1) gene that codes for the CYP2E1 enzyme for activation of procarcinogens [4]. The highest prevalence of NPC in Indonesia is in Yogyakarta $(4.1 \%$ ), followed by Central Java (2.1\%), Bali (2\%), Bengkulu, and Jakarta with $1.9 \%$ respectively [5]. Study of the relationship of CYP2E1 gene polymorphism with the risk of NPC in Yogyakarta with buffy coat isolation DNA of 119 male NPC patients and 119 controls of Javanese men showed mutant alleles at rs3813865 and rs2070672 increased the risk of NPC and the progression of the disease, whereas the mutant allele of rs3813867 reduced the risk of NPC [6].

The rs2070672 polymorphism of the CYP2E1 gene is one of the NPC biomarkers that need to be investigated because there is a strong association between the polymorphism of the rs2070672 CYP2E1 gene with the incidence of NPC. Research on the rs2070672 polymorphism of the CYP2E1 gene in subjects with NPC in Indonesia is still rare, while it has never been studied in Bali.

\section{MATERIAL AND METHODS}

A total of 65 undifferentiated type NPC in Balinese subjects who underwent nasopharyngeal biopsy at Sanglah Hospital and histopathological examination at the Anatomy Pathology Laboratory of the Faculty of Medicine, Udayana University/Sanglah Hospital Denpasar from January 2017 to December 2018 were included in the inclusion criteria. Samples were taken by consecutive sampling. The study was conducted in August - September 2019. This is an observational study with crosssectional comparative study design. Data were analyzed by univariate, bivariate, and multivariate analysis. Characteristics of the study subjects included age, gender, clinical stage of undifferentiated type NPC, and rs2070672 polymorphism of the CYP2E1 gene. The statistical test used was the Chi-Square Test by looking at $95 \%$ confidence interval $(\mathrm{CI})$ and the $\mathrm{p}$ value at the significance of 0.05 . Multivariate analysis was done using logistic regression. Data processing is performed using the SPSS computer program ver. 22.0 for Windows.

\section{RESULT}

This study using 65 samples conducted in August-September 2019.

Table 1. Characteristic of subject

\begin{tabular}{lr}
\hline \multicolumn{1}{c}{ Characteristic } & $\mathbf{n}=\mathbf{6 5}$ \\
\hline Age (year) & \\
Average \pm SD & $48.1 \pm 11.1$ \\
Min-Max & $17-73$ \\
Gender & \\
Male & $48(73.8 \%)$ \\
Female & $17(26.2 \%)$ \\
\hline
\end{tabular}


Table 1 shows that the average age of the subjects was 48.1 years with a standard deviation of 11.1 years. The youngest is 17 years old and the oldest is 73 years old. The gender proportion is male as many as 48 subjects $(73.8 \%)$ and female as many as 17 subjects $(26.2 \%)$.

Table 2. Clinical stage of an undifferentiated type of NPC

\begin{tabular}{|c|c|}
\hline Variable & $\begin{array}{l}(\mathrm{n}=65) \\
\mathrm{n}(\%)\end{array}$ \\
\hline \multicolumn{2}{|l|}{$\mathrm{T}$ (Tumor) } \\
\hline 1 & $1(1.5 \%)$ \\
\hline 2 & $14(21.6 \%)$ \\
\hline 3 & $16(24.6 \%)$ \\
\hline 4 & $34(52.3 \%)$ \\
\hline \multicolumn{2}{|l|}{$\mathrm{N}$ (Nodule) } \\
\hline 0 & $9(13.8 \%)$ \\
\hline 1 & $18(27.7 \%)$ \\
\hline 2 & $16(24.6 \%)$ \\
\hline 3 & $22(33.9 \%)$ \\
\hline \multicolumn{2}{|l|}{ M (Metastasis) } \\
\hline 0 & $63(96.9 \%)$ \\
\hline 1 & $2(3.1 \%)$ \\
\hline \multicolumn{2}{|l|}{ Clinical stage } \\
\hline Stage I & $0(0 \%)$ \\
\hline Stage II & $9(13.8 \%)$ \\
\hline Stage III & $12(18.5 \%)$ \\
\hline Stage IV A & $19(29.2 \%)$ \\
\hline Stage IV B & $25(38.5 \%)$ \\
\hline Early-stage & $9(13.8 \%)$ \\
\hline Advanced stage & $56(86.2 \%)$ \\
\hline
\end{tabular}

Distribution based on the clinical stage of an undifferentiated type of NPC in this study was stage II in 9 subjects (13.8\%), stage III in 12 subjects $(18.5 \%)$, stage IVA in 19 subjects $(29.2 \%)$, and stage IVB as many as 25 subjects (38.5\%). Initial stages were found in 9 subjects (13.8\%) and advanced stages as many as 56 subjects $(86.2 \%)$. This result is in correspond with Hasibuan et al (2014), whose obtain $62.5 \%$ subjects with stage IV NPC and none stage I NPC [7]. Study in Europe obtain as many as 39.1\% of early stage NPC and $60.9 \%$ of late stage NPC [8]. Study in Djamil Hospital Padang obtain as many as $13.64 \%$ of early stage NPC and $86.3 \%$ of late stage NPC. This shows patients come in the late stage. Nasopharyngeal carcinoma often shows minimal or unspecific sign, so it often found in late stage with lymph node enlargement and intracranial invasion [9].

Table 3. Allele and rs2070672 polymorphism CYP2E1 gene

\begin{tabular}{lr}
\multicolumn{1}{c}{ Variable } & $\begin{array}{c}(\mathbf{n = 6 5 )} \\
\mathbf{n}(\%)\end{array}$ \\
\hline Allele rs2070672 CYP2E1gene & \\
Allele AA & $18(27.7 \%)$ \\
Allele AG & $8(12.3 \%)$ \\
Allele GG & $39(60.0 \%)$ \\
Polymorphism & \\
Present & $47(72.3 \%)$ \\
Not present & $18(27.7 \%)$ \\
\hline
\end{tabular}

The proportion of allele rs2070672 CYP2E1 gene in subjects with undifferentiated type NPC in this study was 18 AA allele (27.7\%), AG allele in 8 subjects $(12.3 \%)$, and GG allele in 39 subjects $(60.0 \%)$. Comparison of the proportion of rs2070672 polymorphism of CYP2E1 gene in subjects with undifferentiated type NPC were polymorphisms (allele AG and GG) in 47 subjects $(72.3 \%)$ and no polymorphisms/wild types (AA alleles) in 18 subjects $(27.7 \%)$.

Study by Yin (2012) shows SNP rs2070672 G allele (GG) homozygote found in $7.9 \%$ from 447 subjects compare with $3.1 \%$ from 487 control. GG genotype is related with increased risk NPC compared with GA and AA genotype $(\mathrm{OR}=3.57$ and $9.5 \% \mathrm{CI}=1.66-7.66$ recessive inherited $)[10]$.

Table 4. The proportion of rs2070672 polymorphism CYP2E1 gene based on the clinical stage of undifferentiated type NPC in Balinese

\begin{tabular}{|c|c|c|c|c|}
\hline \multirow{2}{*}{ Variable } & \multicolumn{2}{|c|}{ Polymorphism } & \multirow{2}{*}{ PR 95\% CI } & \multirow[b]{2}{*}{$\mathbf{P}$} \\
\hline & Present & Not present & & \\
\hline \multicolumn{5}{|l|}{ Stage } \\
\hline Advanced & $44(78.6 \%)$ & $12(21.4 \%)$ & $\begin{array}{r}2.357 \\
\end{array}$ & 0.011 \\
\hline Early & $3(33.3 \%)$ & $6(66.7 \%)$ & $(0.926-5.998)$ & \\
\hline
\end{tabular}

In the advanced stage, as many as 44 subjects (78.6\%) and early stages as many as 3 subjects (33.3\%) experienced polymorphism rs2070672 CYP2E1 gene. Patients with advanced-stage NPC as many as 12 subjects (21.4\%) and early-stage as many as 6 subjects $(66.7 \%)$ who did not experience polymorphism in rs2070672 CYP2E1 gene (wild type). Chi-square test results obtained the proportion of polymorphism in the advanced stage is 2.357 times compared to the early stage with a confidence interval (CI) 0.926-5.998 and a $\mathrm{p}$-value $=0.011(\mathrm{P}<0.05)$, meaning statistically significant
Table 5. The result of multivariate analysis (logistic regression)

\begin{tabular}{lccc}
\hline \multicolumn{1}{c}{ Variable } & Adjusted Odds Ratio & 95\% CI & P \\
\hline Polymorphism & 7.469 & $1.586-35.177$ & 0.011 \\
Age & 1.005 & $0.939-1.076$ & 0.877 \\
Gender & 1.553 & $0.289-8.357$ & 0.608 \\
\hline
\end{tabular}

The results of the multivariate analysis using logistic regression proved that the rs2070672 polymorphism of the CYP2E1 gene at an advanced stage was 7.469 times higher than the early stage with a confidence interval (CI) 1.586-35.177 and $\mathrm{P}$-value $=0.011(\mathrm{P}<0.05)$ after controlling for age and sex.

\section{DISCUSSION}

A total of 65 subjects were included in this study with ages ranging from 17 to 73 years with an average age of $48.1 \pm 11.1$ years. This shows that the age distribution in the study subjects is normal and in accordance with the existing literature, NPC rarely occurs at the age of fewer than 20 years. This is consistent with Razek and King's research, which states that the peak age of nasopharyngeal carcinomas is 40-60 years [11]. In Cantonese, the incidence increases with age and peaks at the age of $40-59$ years and then decreases [12]. In Turkey, NPC occurs mostly at the age of $40-50$ years [13]. It is estimated that about $80 \%$ of NPC is found at the age of $35-50$ years with a peak age of 40-49 years [14]. NPC most commonly occurs at the age of 40 - 49 years at Cipto Mangunkusumo Hospital in Jakarta and more than $80 \%$ of patients are diagnosed at the age of $30-59$ years [15].

Cancer cells arise from normal cells that are transformed into malignant due to spontaneous mutations or induction of carcinogens. Long induction time is needed from the time of contact with carcinogens to the appearance of cancer cells, up to 15-30 years [16]. NPC tends to occur at the age of more than 40 years because of a decreased immune system which cannot eliminate tumor antigens or EBV viruses properly. DNA repair mechanism that is not functioning properly causes failure to repair gene mutations resulting in uncontrolled cell growth. The incidence of NPC is often found at the age of more than 40 years related to the length of exposure to carcinogenic substances such as nitrosamines found in salted fish and cigarette consumption for more than 25 years [3].

There were more male than female NPC patients in this study, as many as 48 subjects $(73.8 \%)$, with a ratio of $2.8: 1$. This is consistent with several other studies that found the proportion of men with NPC was greater than women with a ratio of 2-3: 1 [12]. Nurdiansyah et al. stated the ratio of men and women is $2.7: 1$ [13]. Adham et al. stated the comparison according to gender are $70.4 \%$ in men and $29.6 \%$ in women with a ratio of $2.4: 1$ [15]. Hasibuan et al. reported the incidence rate of NPC in males and females was 3: 1 [7]. The high incidence in men is thought to be due to occupational factors and life habits that are more often exposed to carcinogens [13].

The distribution of subjects based on the clinical stage of undifferentiated type NPC in the Balinese was an early stage as many as 9 subjects $(13.8 \%)$ and an advanced stage as many as 56 subjects $(86.2 \%)$. This is in accordance with several studies such as Hasibuan et al. as many as $62.5 \%$ of patients with stage IV NPC and no patient in stage I [7]. Research in Europe found $39.1 \%$ of patients with early-stage NPC and $60.9 \%$ of patients with advanced-stage [7]. Research in Padang Djamil Hospital stated early-stage NPC in $13.64 \%$ and advanced stages in $86.36 \%$. This shows that most of the patients come for treatment at an advanced stage. The diagnosis of NPC is often made late because the location of the nasopharynx is hidden behind the nasal cavity and under the base of the skull so that NPC patients generally come for treatment at an advanced stage. In addition, NPC often exhibits minimal or nonspecific symptoms so it often found at an advanced stage with enlarged lymph nodes and intracranial invasion [9].

The description of the rs2070672 allele CYP2E1 gene in undifferentiated type NPC patients in Balinese was AA allele in 18 subjects (27.7\%), AG allele in 8 subjects (12.3\%), and GG allele in 39 subjects $(60.0 \%)$. This shows that the majority of NPC patients in this study experienced polymorphisms (alleles AG and GG) as many as 47 subjects $(72.3 \%)$ 


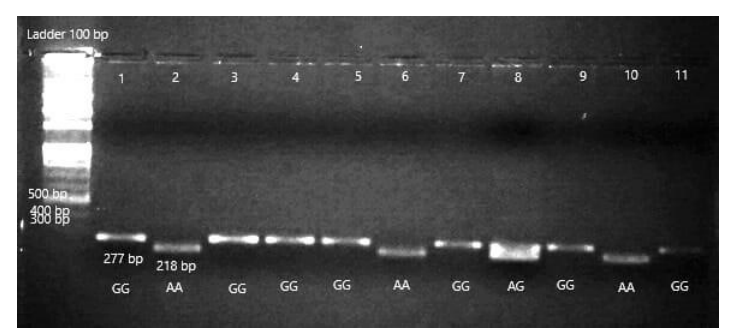

Picture 1. The result of ARMS-PCR primary tetra to detect allele rs2070672 in this study

This is consistent with the results of several previous studies. Yin stated homozygous SNP rs2070672 allele G (GG) was present in 7.9\% of 447 NPC patients compared with $3.1 \%$ of 487 controls. Genotype GG is associated with an increased risk of NPC compared to GA and AA genotypes (OR=3.57 and $95 \% \mathrm{CI}=1.66-7.66$ which inherited recessively) [10].

Tang et al. comparing NPC patients in several cities e.g Shantou, Shanghai, Shenyang, Xian, and China with a total of 400 NPC patients. In each city, several specific rs genes were compared as risk factors for nasopharyngeal carcinoma. The study sample was 100 NPC patients in each of these cities, which consisted of 50 male patients and 50 female patients, aged 18-53 years. The proportion of polymorphism rs2070672 alleles G rs2070672 in each city is as follows: Shantou (18.8\%), Shanghai $(14.1 \%)$, Shenyang $(18.8 \%)$, Xian (21.9\%), and China (18.4\%). This study also compared polymorphisms on rs2070672 with other ethnicities. In this study (China), the polymorphism of rs 2070672 was $33.9 \%$ from 400 samples where the proportion was higher than that of Northern Europe $(5.2 \%$ of 115 subjects), Germany $(3.7 \%$ of 299 subjects), and Turkey (6, 8\% of 206 subjects) [18].

A case-control study by Wang et al in the Chinese Tibet population where 50 patients NPC as case and 50 patients as control, showing G allele polymorphism in 30 subjects in case group and 5 subjects in control group. This result is higher than the proportion of $\mathrm{G}$ allele rs2070672 in AfricaAmerica, Europe-America, and Korea. This result is statistically significant with $\mathrm{P}$-value $=0,01(\mathrm{P}<0.05)$ and allele GG polymorphism increased the risk of NPC to 2.9 times [19].

In this study, polymorphism was found in the rs2070672 CYP2E1 gene at an advanced stage as many as 44 subjects $(78.6 \%)$ and in the early stages as many as 3 subjects (33.3\%). Subjects with advanced stage NPC were 12 subjects $(21.4 \%)$ and early-stage were 6 subjects $(66.7 \%)$ who did not experience polymorphism in the rs2070672 CYP2E1 gene (wild type). Chisquare test shows the proportion of polymorphism in the advanced stage 2.357 times compared to the initial stage with a confidence interval (CI) 0.926-5.998 and $\mathrm{P}=0.011(\mathrm{P}<0.05)$ so statistically significant.

The results of the multivariate analysis using logistic regression proved that the rs2070672 polymorphism of the CYP2E1 gene at an advanced stage was 7.469 times higher than the initial stage with a confidence interval (CI) 1.586-35.177 and a value of $\mathrm{P}=0.011(\mathrm{P}<0.05)$ after controlling for age and sex. Yin's study of the rs2070672 polymorphism in NPC patients in Malaysia reported statistically significant results with a P-value of 0.04 $(\mathrm{P}<0.05)$ and the probability of the occurrence of $\mathrm{GG}$ and $\mathrm{AG}$ allele polymorphisms in the rs2070672 CYP2E1 gene in undifferentiated type NPC was 1.25 times greater in patients with advanced stages [10].

A case-control study by Wang et al. in the Tibetan Chinese population, there is a chance that the rs2070672 polymorphism of the CYP2E1 gene in undifferentiated type NPC is 2.6 times greater in patients with advancedstage with $95 \%$ CI values of 1.2-5.7 [19]. Examination of the rs 2070672 allele polymorphism of the CYP2E1 gene can be used as a supporting modality to assess tumor growth, progression, and disease prognosis. This is in accordance with several previous studies whose found alleles polymorphism of the rs 2070672 CYP2E1 gene was significantly associated with cancer metastasis to the lymph nodes and the clinical stage [18].

An increase in the proportion of rs2070672 polymorphism of the CYP2E1 gene is associated with worse overall survival (OS) and diseasefree survival (DFS) on observation for 5 years. The alleles polymorphism of the rs2070672 CYP2E1 gene can be used as a prognostic factor for NPC [20]. Gene polymorphisms related to carcinogenic metabolism are one of the risk factors for NPC. One of them is the cytochrome P450 gene family 2 subfamily E polypeptide 1 (CYP2E1) which codes the CYP2E1 enzyme for activation of procarcinogens [19].

\section{CONCLUSION}

There is a difference in the proportion of rs2070672 polymorphism of the CYP2E1 gene in patients with an undifferentiated type of NPC in Balinese, which advanced stage is 2.357 times higher than the early stage..

\section{REFERENCE}

[1] Duvvuri, U., Kubicek, G.J. 2014. Principles of Radiation Oncology. In: Johnson, J.T., Rosen, C.A., editors. Bailey's Head and Neck Surgery Otolaryngology. 5th. Ed. Philadelphia:Lippincott Williams \& Wilkins. p. 125-132.

[2] Murtiono W. 2013. Pengaruh Radioterapi Eksterna Terhadap Penurunan Kualitas Hidup Penderita Karsinoma Nasofaring WHO tipe III. Tesis. Bagian Ilmu Kesehatan Telinga Hidung Tenggorok Bedah Kepala Leher Fakultas Kedokteran Universitas Padjajaran. Bandung.

[3] Tsao, S.W., Yip, Y.L., Tsang, C.M., Pang, P.S., Lau, V.M.Y., Zhang, G., et al. 2014. Etiological Factors of Nasopharyngeal Carcinoma. Oral Oncol. 50:330-338.

[4] Danko, I.M., Chaschin, N.A. 2015. Association of CYP2E1 Gene Polymorphism with Predisposition to Cancer Development. Exp. Oncol. 27:248-256.

[5] Balitbang Kemenkes RI. 2013. Riset Kesehatan Dasar (RISKESDAS). Jakarta: Balitbang Kemenkes RI.

[6] Suhda, S., Paramita, D.K., Fachiroh, J. 2016. Tetra Primer ARMS PCR Optimization to Detect Single Nucleotide Polymorphisms of the CYP2E1 Gene. Asian Pac. J. Cancer Prev.. 17:3065-3069.

[7] Hasibuan, N.R., Farhat, Haryuna, T.S.H., Yudhistira, A. 2014. Korelasi Positif Ekspresi Cyclooxygenase-2 dengan Microvessel Density pada Karsinoma Nasofaring. ORLI. p. 34-43.

[8] Cheng, D., Kong, H., Li, Y. 2014. Prognostic Value of Interleukin-8 and MMP-9 in Nasopharyngeal Carcinoma. Eur. Arch. Otorhinolaryngol. 271:2580.

[9] Faiza, S., Rahman, S., Asri, A. 2015. Karakteristik Klinis dan Patologis Karsinoma Nasofaring di Bagian THT-KL Dr. M. Djamil Padang. Jurnal Kesehatan Andalas. 5:90-95.

[10] Yin, Y.P. "Genetic Polymorphisms Associated With Nasopharyngeal Carcinoma Susceptibility in Malaysian Chinese" (disertasi). Kuala Lumpur: Universitas Malaya.

[11] Razek, A.A., King, A. 2012. MRI and CT of Nasopharyngeal Carcinoma. Am. J. Roent. 198:11-18.

[12] Cao, S., Simons, M., Qian, C. 2011. The Prevalence and Prevention of Nasopharyngeal Carcinoma in China. J. Chi. Anti-Can. 30:114-119.

[13] Turkoz, F.P., Celenkoglu, G., Dogu, G.G., Kalender, M.E., Coskun, U., Alkis, N. 2011. Risk Factors of Nasopharyngeal Carcinoma in Turkey - an Epidemiological Survey of the Anatolian Society of Medical Oncology. Asian Pac. J. Cancer Prev. 12: 3017-3021.

[14] Handayani, K., I.G.N.P. Putra, A.A.B.N. Nuartha. 2014. Kebutaan pada Karsinoma Nasofaring. CDK. 214:41-43.

[15] Adham, M., Kurniawan, A.N., Muhtadi, A.I., Roezin, A., Hermani, B., Gondhowiardjo, S., Tan, I.B., Middledorp, J.M. 2012. Nasopharyngeal Carcinoma in Indonesia: Epidemiology, Incidence, Signs, and Symptoms at Presentation. Chin. J. Cancer. 31:185-196.

[16] Sukardja, I.D.G. 2010. Onkologi Klinik. 2nd. Ed. Surabaya: Airlangga University Press. p.65.

[17] Nurdiansyah, F., Pardede, S.A., Farhat, Munir, D., Asnir, R.A., Hasibuan, M., Eyanoer, P.C. 2013. Korelasi Ekspresi Cyclooxygenase-2 (COX-2) dan TNF- $\alpha$ Sebagai Mediator Cancerrelated Inflammation Pada Karsinoma Nasofaring. ORLI. 43:91-100.

[18] Tang, K., Li, X., Xing, Q., Li, W., Feng, G., He, L., dkk. 2010. Genetic Polymorphism Analysis of Cytochrome P4502E1 (CYP2E1) in Chinese Han Populations from Four Different Geographic Areas of Mainland China. Genomics. 95:224-229.

[19] Wang, L., Ren, G., Li, J., Zhu, L., Niu, F., Yan, M., Li, J., Yuan, D., Jin, T. 2017. Genetic Polymorphism Analysis of Cytochrome P4502E1 (CYP2E1) in a Chinese Tibetan Population. Medicine. 96:47-51.

[20] Jia, W.H., Qin, H.D. 2012. Non-viral Environmental Risk Factors For Nasopharyngeal Carcinoma: A Systematic Review. Semin Cancer Biol. 22:117-126. 